\title{
MIR92A2 wt Allele
}

National Cancer Institute

\section{Source}

National Cancer Institute. MIR92A2 wt Allele. NCI Thesaurus. Code C82048.

The human MIR92A2 wild-type allele is located in the vicinity of Xq26.2 and is approximately $74 \mathrm{~b}$ in length. This allele, which encodes MIR92A2 pre-miRNA, plays a role in the regulation of gene expression. Alteration in the expression of this gene is associated with the development of hepatocellular carcinoma and meduloblastoma. 